Çukurova Üniversitesi Mühendislik Mimarlık Fakültesi Dergisi, 34(2), ss. 155-170 Haziran 2019

Çukurova University Journal of the Faculty of Engineering and Architecture, 34(2), pp. 155-170, June 2019

\title{
Gövdesi Dolu ve Dairesel Boşluklu Yalıtımsız Kompozit Döşeme Kirişlerinin Yangın Davranışının Deneysel İncelenmesi
}

\author{
Pınar SUNAR BÜKÜLMEZ*1, Oğuz Cem ÇELİK \\ ${ }^{1}$ Ístanbul Teknik Üniversitesi, Yapı Bilimleri Doktora Programı, Mimarlık Ana Bilim Dalı, \\ Istanbul \\ ${ }^{2}$ Ístanbul Teknik Üniversitesi, Mimarlık Fakültesi, Yapı ve Deprem Mühendisliği Çalışma \\ Grubu, İstanbul
}

Geliş tarihi: 15.01.2019

Kabul tarihi: 08.04.2019

\section{Öz}

Büyük açıklıklar geçebilen ve mimari davranış olarak diğer boşluklu kirişlere göre daha avantajlı olan dairesel gövde boşluklu kirişlerin üstün yapısal özelliklerine karşın yüksek sıcaklıklarda mekanik özelliklerinde önemli ölçüde azalmalar olduğu bilinmektedir. Türkiye’de ilk kez dairesel gövde boşluklu kompozit kirişlerin yangın performanslarının tahminine yönelik bir deney modeli geliştirilmiş ve tam ölçeğe yakın deneyler gerçekleştirilmiştir. Çalışma kapsamında, biri dolu ve diğeri gövdesi dairesel boşluklu IPE 140 profilinden üretilmiş kompozit kirişlerin varsayılan servis yükleri ve ISO 834 standart yangın eğrisi altındaki göçme davranışları incelenmiştir. Yangın sonrası çelik malzemenin mekanik özelliklerinde meydana gelen değişiklikler ayrıca kaydedilmiştir. Sonuç olarak, yalıtımsız ve dolu gövdeli DK-R numunesi beklenildiği üzere yalıtımsız gövde boşluklu GBK-YS numunesine göre daha uzun süreli yangın dayanımı sağlamıştır. Böylece, gövde boşluklarının erken göçmelere neden olarak yangın dayanımı önemli düzeyde azalttığı, koruma olmaksızın yönetmeliklerde öngörülen dayanımlara ulaşılamayacağı anlaşılmaktadır.

Anahtar Kelimeler: Dolu gövdeli kiriş, Dairesel gövde boşluklu kiriş, Kompozit, Yangın deneyleri

\section{Fire Testing and Behavior of Unprotected Solid and Cellular Steel-Concrete Composite I-Beams}

\begin{abstract}
Cellular beams provide architects and engineers with lightweight structural solutions for spanning large areas. However, web cut-outs may lead to a significant decrease in mechanical properties at elevated temperatures.. An experimental model and near full-scale fire testing have been conducted for the first time in Turkey to better estimate fire performances of steel-concrete composite floor beams with and without circular web openings. Within the context of this experimental work, two composite beams made of IPE 140 rolled sections with solid and open webbed configurations and under assumed service loading are tested to failure following the ISO 834 fire conditions. Additionally, variations in mechanical properties of the materials used are determined after testing. As a result, unprotected solid webbed DK-R specimen provided a longer fire resistance than the unprotected cellular beam GBK-YS as expected. This reveals that web openings in composite beams have a pronounced impact on fire resistance of such
\end{abstract}

*Sorumlu yazar (Corresponding author): Pınar Sunar Bükülmez, pinar.sunar@arc.bau.edu.tr 
Gövdesi Dolu ve Dairesel Boşluklu Yalıtımsız Kompozit Döşeme Kirişlerinin Yangın Davranışının Deneysel Incelenmesi

beams, leading to premature failures. Therefore, such beams may not reach the predetermined fire strengths without implementing an appropriate protection against fire.

Keywords: Solid webbed beam, Cellular beam, Composite, Fire tests

\section{GíRIŞ}

Büyük açıklıklar geçebilen, mimari ve davranış olarak diğer boşluklu kirişlere göre daha üstün özellikleri bulunan dairesel gövde boşluklu kirişlerin üstün yapısal özelliklerine karşın, yüksek sıcaklıklarda mekanik özelliklerinde önemli ölçüde azalmalar olduğu bilinmektedir [1,2]. Bu tür kirişlerin yangın karşısında davranışlarının tam olarak bilinmemesi, alınacak pasif ve aktif önlemlerin bazen gereğinden fazla, bazen de yetersiz olmasına yol açmaktadır.

2001'de Amerika'da meydana gelen WTC İkiz Kuleler'deki göçmeler sonrasında çelik yapıların yüksek sıcaklıklar karşısındaki yapısal davranışlarının incelenmesi daha da önem kazanmış, bu kapsamda özellikle Amerika ve Avrupa'da yapılan deneyler artmıştır. Daha güncel olarak, 14 Haziran 2017'de Londra'da Grenfell Tower yangını ve doğurduğu sonuçlar özellikle çok katlı binalardaki yangın güvenliği konusunu her düzeyde tekrar gündeme getirmiştir. Çelikbetonarme kompozit döşeme-kiriş sistemlerinin yüksek sıcaklıklardaki davranışları üzerine birçok çalışma yapılmıştır [3-6]. Çalışmalar farklı ölçeklerde olmalarının yanısıra, döşeme kirişlerinin dolu ve boşluklu olarak seçilmesine bağlı olarak değişiklikler göstermektedir.

Gövdesi boşluklu kirişlerin yangın performanslarıyla ile ilgili öncü çalışmalar Bailey [3] tarafindan yapılmış, gövdesi boşluklu ve boşluksuz çelik kirişlerde ulaşılan sıcaklıklar üzerine yoğunlaşılmıştır. Çalışma, yükleme yapılmadan gerçekleştirilen deneylerde gövdesi boşluklu ve dolu kirişlerde gövdenin boş ve dolu bölümlerinde meydana gelen sıcaklık farklarının analizi ile sınırlandırılmıştır.

Bihina ve arkadaşları [4] doğal yangın koşulları altında korunmamış kompozit gövde boşluklu kirişlerin sıcaklık dağılımlarını, yerdeğiştirme ve şekil değiştirmelerini deneysel olarak incelemişlerdir. Kirişlerde göçme modu yanal gövde burkulmaları şeklinde olup kiriş merkezinde döşeme dönüşüne bağlı olarak dişa doğru eğilmeler ve yanal burkulmalar gözlenmiştir.

Bihina ve arkadaşları [5] tarafından yapılan dört tam ölçekli deney, farklı dairesel geometrilere sahip simetrik ve asimetrik kompozit boşluklu kirişlerin yüksek sıcaklıklardaki davranışlarını ölçmek amacıyla gerçekleştirilmiştir. Kirişlerde göçme, gövde burkulması ile birlikte boşluk üstü ve altı $\mathrm{T}$ kesit elemanlarında yırtılmalar olarak gözlenmiştir.

Selamet ve arkadaşları [6] ISO 834 yangın eğrisi altında çelik-betonarme kompozit kat döşemesi yangın deneyi yapılmıştır. Beton döşemenin membran davranışı incelenmiştir. Deney sonucunda döşemenin membran etkisi ile yangın boyunca taşıyıcılığı devam ettirdiği izlenmiştir. Buna bağlı olarak da ikincil çelik kirişlerin yalıtımsız kalabileceği belirtilmiştir.

Gövdesi dolu ve boşluklu, yalıtımsız kirişlerde yapılan bu deneysel çalışma ile kirişlerin yüksek sıcaklıklardaki performanslarının belirlenmesi ve göçme biçimlerinin karşılaştırılması amaçlanmaktadır. Böylece literatürde oldukça sınırlı olan deneysel çalışmalara katkıda bulunmak hedeflenmiştir.

Çalışmada kullanılan dolu ve dairesel gövde boşluklu kompozit I-kirişler yüksek sıcaklıklarda farklı özellikteki kirişlerin göçme durumlarının incelenmesine olanak sağlayacak şekilde tasarlanmıştır. Uygun yükleme değerleri kullanılmıştır. Numunelerin tasarımında ölçek faktörü oluşturulmamaya, olabildiğince gerçek boyutlara gidilmeye çalışıllmıştır. 


\section{YANGIN DAYANIM DENEYLERI}

\subsection{Deney Numuneleri}

Deney düzeneğinde getirdiği rahatlıklar nedeniyle, pek çok çalışmada da olduğu gibi $[7,8]$ deneyde kullanılacak kirişlerin tali kiriş olarak alınmasına karar verilmiştir. Kiriş açıklığı, firın boyutları (4150 mm x 5155 mm x 3620 mm) gözönüne alınarak belirlenmiştir. Yüksek sicaklıklarda değişik durumlar için yerdeğiştirmelerin ve göçme durumlarının izlenmesi/belirlenmesi amaçlanmaktadır. Deney için seçilen profil $\mathrm{L}=4.715 \mathrm{~m}$ açıklık geçen IPE140 çelik hadde profili olup çelik kalitesi
S275JR olarak belirlenmiștir. Biri dolu gövdeli referans numunesi (DK-R), diğeri dairesel gövde boşluklu numune (GBK-YS) olmak üzere iki numune seçilmiştir. Aynı koşullarda denenmesi ve boşlukların etkisini tam olarak izleyebilmek amacıyla dolu gövdeli numune iki adet IPE 140'ın kesilip kaynaklanması ile aynı yüksekliğe getirilmiştir (Şekil 1a). Yalıtımsız gövde boşluklu numune Şekil 1b'de verilmiştir. Boşluk yüksekliği ve ardışık boşlukların arasında kalan dolu gövde parçaları olabildiğince olumsuz bir durumu yansitacak şekilde seçilmiştir. Boşluk yüksekliği/çelik kiriş yüksekliği oranı maksimuma oldukça yakın bir değer olan 0,70 alınmıştır.
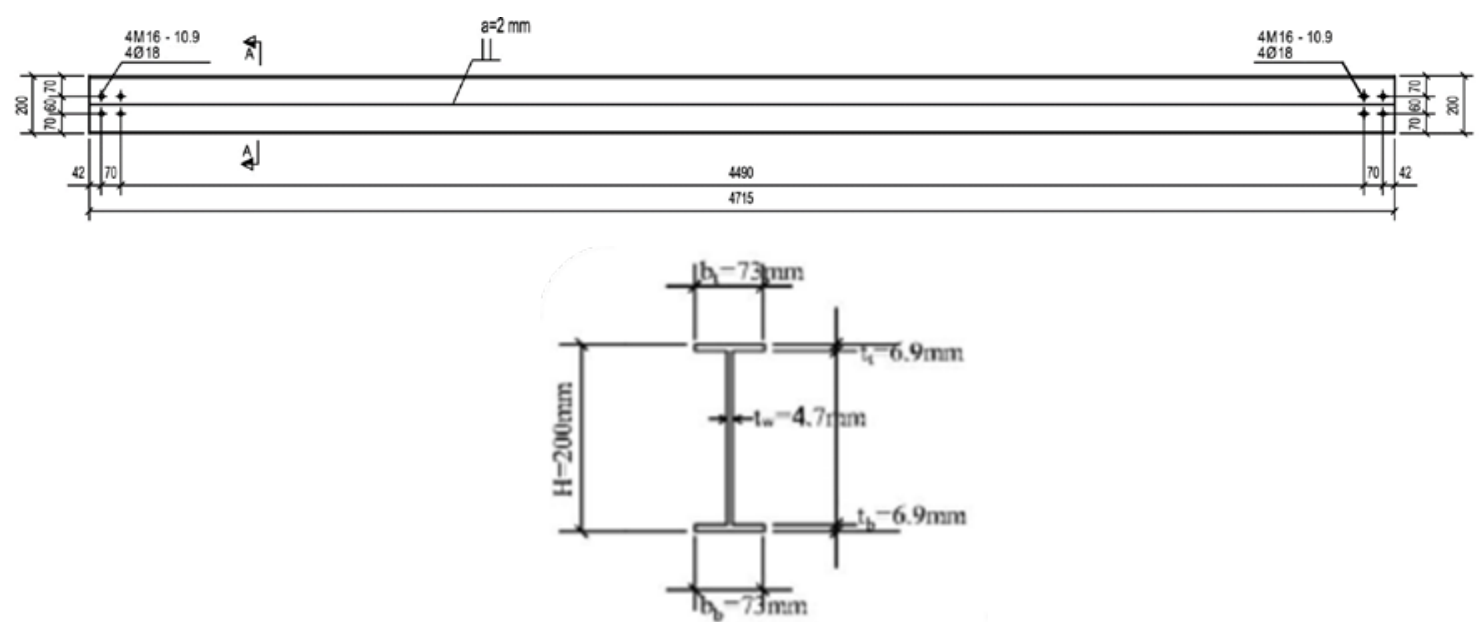

(a)

A-A

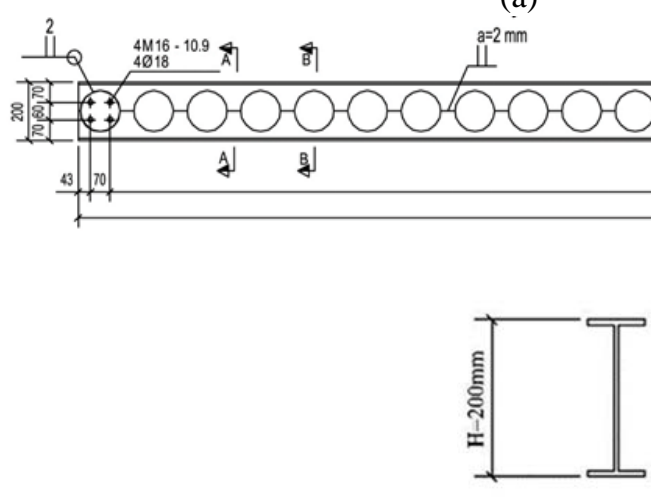

(b)
A-A

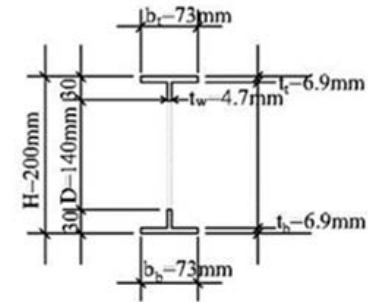

B-B

Şekil 1. Numunelerin üretim çizimleri: (a) DK-R numunesinin üretim çizimleri, (b) GBK-YS numunesinin üretim çizimleri 
Gövdesi Dolu ve Dairesel Boşluklu Yalıtımsız Kompozit Döşeme Kirişlerinin Yangın Davranışının Deneysel Incelenmesi

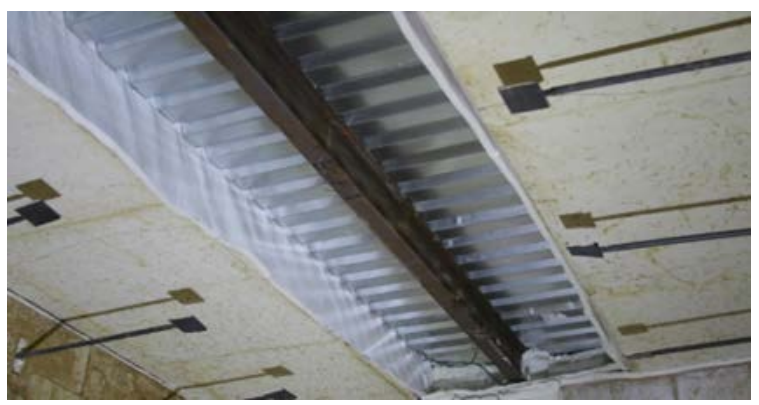

(a)

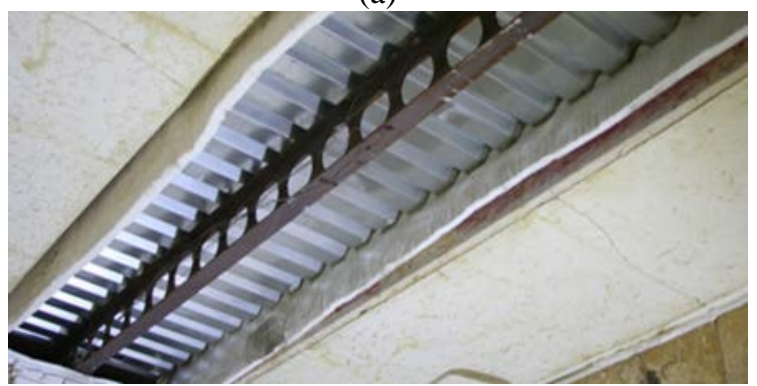

(b)

Şekil 2. Deney öncesi numunelerin genel görünümü: (a) DK-R numunesinin görünümü, (b) GBK-YS numunesinin genel görünümü

Kirişlerin üzerinde 38/151 tipinde, hadve sayısı $\mathrm{n}=6$, kalınlığ $\mathrm{t}=0,7 \mathrm{~mm}$ olan galvanizli kompozit döşeme sacı ve $\mathrm{h}_{\mathrm{f}}=7,8 \mathrm{~cm}$ kalınlığında, $\mathrm{b}_{\text {eff }}=1 \mathrm{~m}$ genişliğinde, C25 kalitesinde beton ve Q188/188 hasır çelik donatı kullanılarak oluşturulan kompozit döşeme sistemi kullanılmıştır (Şekil 2). Kompozit sistemde kayma bağlantısı olarak Ø19/75 mm ölçülerinde Nelson başlıklı saplama (shear stud) kullanılmıştır. TS EN 1363-1 (Yangına Dayanıklılık Deneyleri-Bölüm1: Genel Kurallar) [9] standardı uyarınca betonarme elemanlar ya da beton içeren yangın deneylerinde betonun deneye girmeden önce kuruma süresi en az 3 ay (90 gün) olarak belirtilmiştir. Bu kurala uyulmuş, numuneler deney gününe kadar uygun koşullarda kurumaya bırakılmıştır.

Yangın deneylerinde kullanılacak olan çelik profillerin mekanik özelliklerini belirleyebilmek amacıyla çekme/malzeme (kupon) deneyleri yapılmıştır. Çelik kirişler için TS EN ISO 6892-1 [10] standardına göre çekme numunesi boyutları belirlenmiştir.

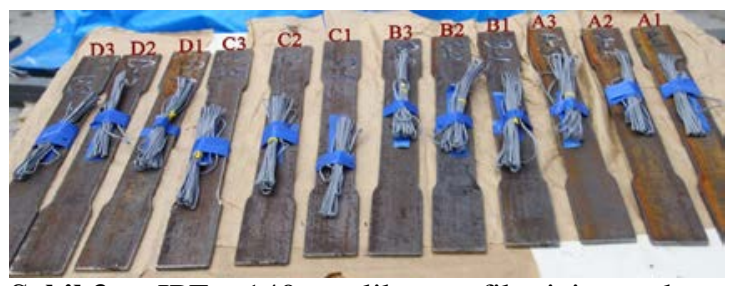

Şekil 3. IPE 140 çelik profil için çekme numunelerinin üzerine şekil değiştirme ölçerlerin (strain gauge) yerleştirilmesi.

Şekil değiştirmelerin ölçülmesinde numune üzerine ekstansometre ve yaprak tipinde TML-YFLA-10-3L akma sonrası okumalar da yapabilen şekil değiştirme ölçerler (strain gauges) yerleştirilmiştir (Şekil 3). Numunelerin akma ve kopma dayanımlarını tam olarak belirleyebilmek ve gerilme-şekil değiştirme eğrilerini elde edebilmek için yangın deneylerinde kullanılan hadde profillerinden toplam 6 adet çekme numunesi için malzeme deneyleri yapılmış, gerilme-şekil değiştirme eğrileri elde edilmiştir. Numunelerin çekme deney sonuçlarından elde edilen gerilme-şekil değiştirme eğrileri Şekil 4'de verilmiştir. 


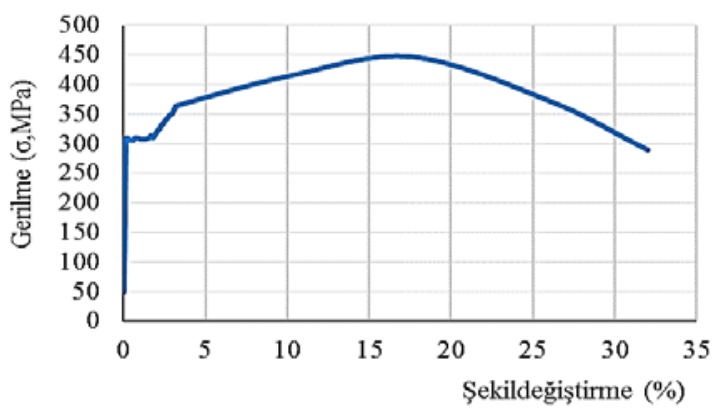

(a)

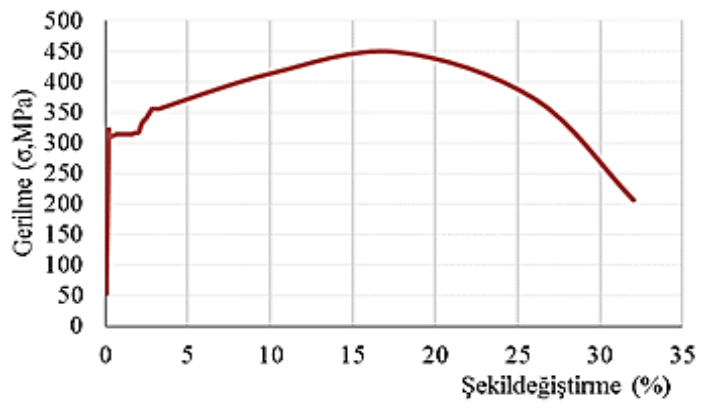

(b)

Şekil 4. Kupon numunelerin çekme deneyi sonuçları: (a) DK-R numunesinin gerilme-şekildeğiştirme eğrisi, (b) GBK-YS numunesinin gerilmeşekildeğiştirme eğrisi

Çekme deneyleri sonucunda dolu gövdeli kiriş numunesi (DK-R) için çekme deneyi sonrası ortalama akma gerilme değeri $\sigma_{\mathrm{A}}=313 \mathrm{MPa}$, ortalama çekme dayanımı $\sigma_{C}=448 \mathrm{MPa}$, ortalama kopma gerilmesi $\sigma_{K}=300 \mathrm{MPa}$ ve toplam uzama miktarı ortalama \%31,1 olarak bulunmuştur. Yalıtımsız gövde boşluklu numune (GBK-YS) için elde edilen akma gerilmesi ortalaması $\sigma_{\mathrm{A}}=314 \mathrm{MPa}$, çekme dayanımı ortalaması $\sigma_{C}=450 \mathrm{MPa}$, kopma gerilmesi ortalamas 1 $\sigma_{\mathrm{K}}=210 \mathrm{MPa}$ ve numunelerin toplam uzama miktarı ortalama \%32,7 olarak belirlenmiştir.

\subsection{Deney Düzeneği ve Mekanik Yükleme}

Deneyler Türkiye'nin ilk akredite yangın deney laboratuvarı olan ve Kocaeli'nde yer alan Efectis Era Avrasya firmasının yangın firını kullanılarak yapılmıştır. Fırın boyutları 4150 mm x 5155 mm x 3620 mm’dir (Şekil 5a). Fırın tasarımı
EN 1363-1'e (Yangına dayanıklılık deneyleri) [11] esas alınarak gerçekleştirilmiştir. Fırın içerisinde her iki yan duvarda 7 adet olmak üzere toplam 14 brülör yer almaktadır (Şekil 5b). Brülörlerin güçleri $500 \mathrm{~kW}$ olup doğalgaz ile çalışmaktadır. Fırın duvarları taşıyıcı çelik iskelet ve yalıtımlı ateş tuğlası duvarlardan meydana gelmekte olup toplam kalınlığı $56 \mathrm{~cm}$ 'dir. Numuneler firın içerisine yatay olarak yerleştirilmiş, 1S1 kaybını önlemek amacıyla numune etrafinda seramik yünü kullanılmıştır. Her bir numune ayrı ayrı denenmiştir.

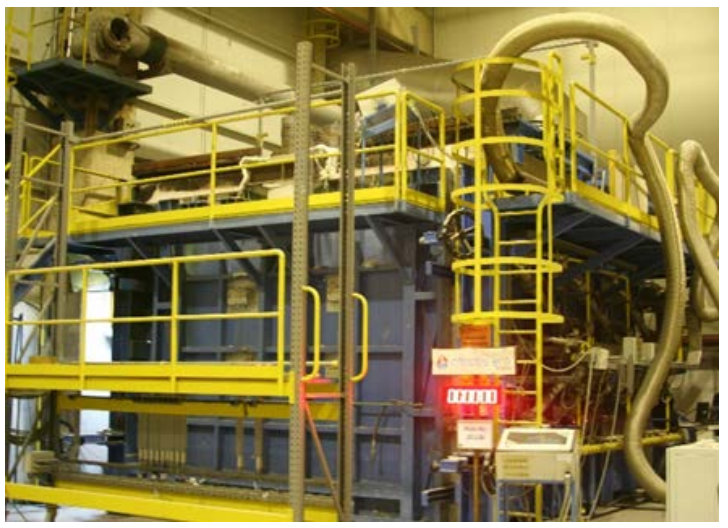

(a)

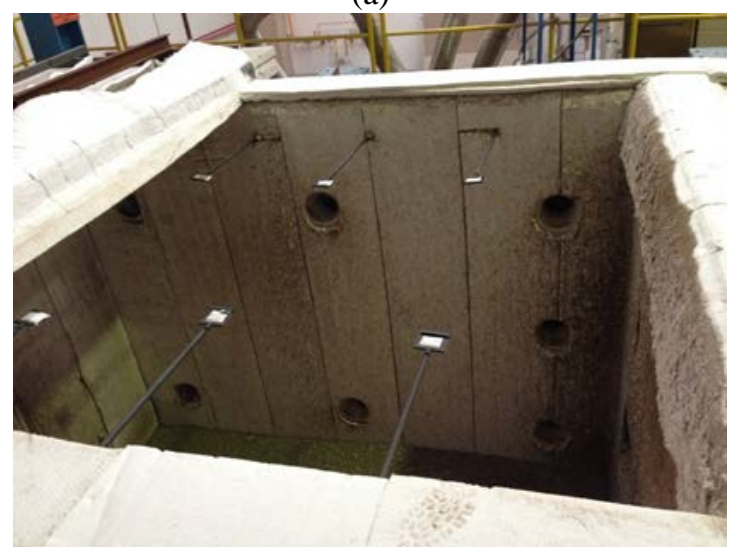

(b)

Şekil 5. Deney fırının görünümleri: (a) Yandan görünüm, (b) İç görünüm

Gövdesi dolu ve boşluklu kompozit kirişlerin sıcaklık ve buna bağlı yerdeğiştirmeleri belirleneceği için önerilen çalışmada literatürde bu tip deneylerde olduğu gibi [12-16], standart yangın eğrilerinden olan selülozik standart yangın eğrisi 
Gövdesi Dolu ve Dairesel Boşluklu Yalıtımsız Kompozit Döşeme Kirişlerinin Yangın Davranışının Deneysel Incelenmesi

(ISO 834) [17] kullanılmıştır. Standart yangın eğrileri birçok yangın deneyinde kullanılmış olup yapı elemanlarının yangın etkisindeki davranışlarını analiz etmeye yönelik olan yangın eğrileridir. Deneyler sirasinda ISO 834'e göre izlenen sıcaklık-zaman ilişkisi ve grafiği Şekil 6’da yer almaktadir.

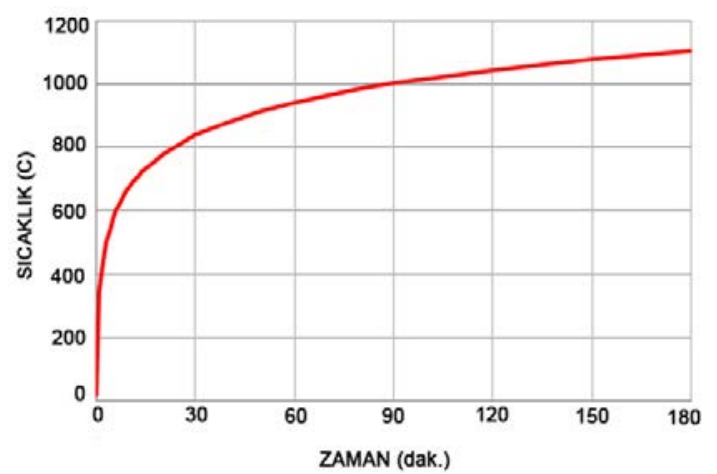

Şekil 6. ISO 834 standart yangın eğrisi

Deney senaryosunda denenecek kirişlerin bir kütüphane binasının döşeme kirişleri olduğu kabul edilmiştir. TS 498 [18] standardında belirtildiği üzere kütüphane yapısı için yapıya etkiyen yük (kompozit döşeme ve kiriş sisteminin ağırlığına ek olarak), hareketli yükler $\mathrm{q}=500 \mathrm{~kg} / \mathrm{m}^{2}$ ve mimari yük seçilen döşeme katmanlarına bağlı olarak yaklaşık $g=150 \mathrm{~kg} / \mathrm{m}^{2}$ 'dir. Böylece, bir kirişe etkiyen toplam yük $\mathrm{p}=650 \mathrm{~kg} / \mathrm{m}^{2}$, diğer bir deyişle toplam 3,06 ton olarak hesaplanmıştır; kirişler taşıma gücüne göre arttırılmış yükler dikkate alınarak hesaplanmış, öz ağırlık modelde dikkate alınmıştır. Laboratuvar ortamında yükleme hidrolik krikolar ile olabildiği gibi metal diskler kullanılarak da yapılabilmektedir. Bu çalışmada, görsel durumu daha iyi yansitabilmek amaciyla ve daha yayılı bir yükleme yapabilmek için yatayda yerleştirilmiş olan kiriş-döşeme sisteminde yayılı yük metal diskler kullanılarak sağlanmıştır.

Metal disk bloklarının her birinde 20 adet disk olup $200 \mathrm{~kg}$ yük sağlanabilmektedir. Bu disklerden 15 adet kullanılarak gerekli yayılı yük elde edilmiştir (Şekil 7). Yükleme protokolü TS EN 1363-1 [9] standardında belirtildiği üzere yapılmıştır. Yükleme, döșeme üzerinde mümkün olduğunca yerdeğiştirmeyi ölçen lineer cetvellerin konumları dikkate alınarak, simetrik yapılmış ve deneyler başlamadan genel olarak yaklaşık 1 saat önce tamamlanmıştır.

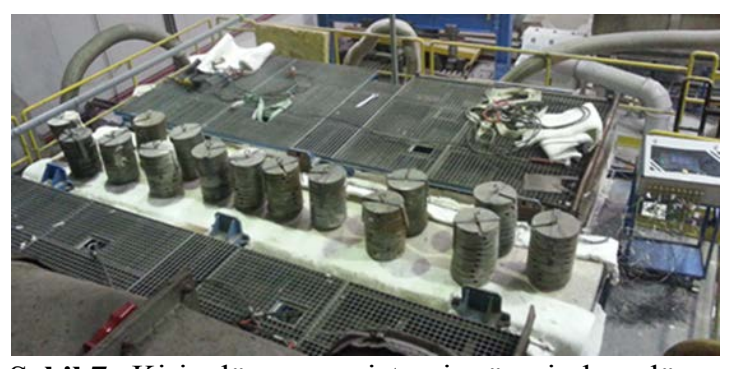

Şekil 7. Kiriş-döşeme sistemi üzerinde düşey yüklerin dağılımı.

\section{3. Ölçüm Cihazları ve Numune Üzerine Yerleştirilmesi}

Deney fırını içerisindeki gazın ve gövdesi boşluklu çelik kirişlerin zamana bağlı sıcaklık değişimleri 1sil çiftler (thermocouples) kullanılarak ölçülmüştür. Yüksek sıcaklıklarda kirişlerde meydana gelen değişimler yerdeğiştirme ölçerler (lineer cetveller) ile belirlenmiştir (Şekil 8 a, b). Deney fırını içerisindeki gazın ölçümü TS EN 1365-3 [19]'de belirtildiği gibi firın tabanına ve duvarlarına yerleştirilmiş olan 8 adet plaka isıl çiftler tarafından izlenmiştir.

Gövdesi dolu ve boşluklu çelik kirişlerin zamana bağlı sicaklık değișimleri ise $1200^{\circ} \mathrm{C}$ 'ye kadar dayanıklı mineral izoleli $\mathrm{K}$ tipi 1 sıl çiftler kullanılarak izlenmiştir. Her deneyde ölçümleri doğru yapabilmesi için, bunlar inconel yalıtıml, yalıtım sonrası teflon kaplı olarak seçilmiştir. Mineral izoleli isılçiftlerin çaplarının küçük olması ve firın içerisinde bükülebilir olması ve kablo gibi dolaştırılabilme özelliği nedeniyle yangın deneylerinde sıkça kullanılmaktadır. Isıl çift sıcaklık ölçerler her kirişin mesnete yakın olan ve kiriş açıklığının orta noktasına denk gelen üst, alt başlık ve gövde kısımlarında kritik noktalara yerleştirilmiștir. Her bir kiriște 14 adet olmak üzere toplam 56 ssıl çift kullanılmıştır. Isıl çift sıcaklık ölçerlerin yerleşimleri daha iyi bir karşılaştırma yapabilmek için her iki deney düzeneğinde de aynıdır (Şekil 9 a, b, c, d, e, f). 
Yüksek sıcaklıklarda meydana gelecek yerdeğiştirmeler ani ve önemli değerlere vardığından, deneyde kullanılan yerdeğiştirme ölçerler bu değerleri ve hızı belirleyebilmek amacıyla kullanılmıştır. Düşey yerdeğiştirmeler laboratuvar ortamında lineer cetvel ile ölçülmektedir. Her deneyde ölçümleri doğru yapabilmesi amacıyla hassaslıkla yerleştirilmiş 7 adet lineer cetvel kullanılmıştır. Lineer cetvellerin numune üzerindeki yerleşimleri (LC1, LC2, LC3, LC4, LC5, LC6, LC7) Şekil.9g üzerinde verilmiştir. Deneylerde TS EN 1365-3 [19], EN 1365-3 [20], standartlarında belirtildiği üzere yangın durumunda yükleme yapılmış bir kirişte meydana gelecek maksimum yerdeğiştirme, bir başka deyişle göçme sınırı L (açıklık)/20 olarak belirtilmiştir.

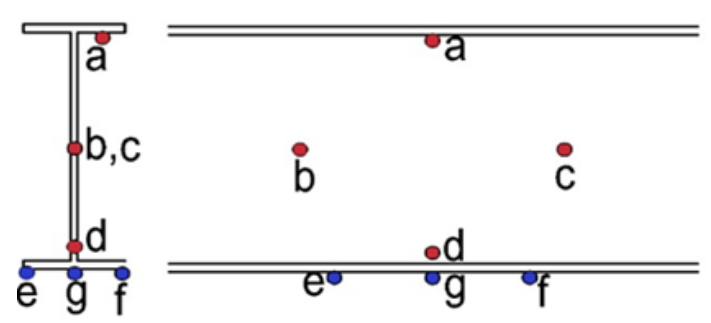

(a)
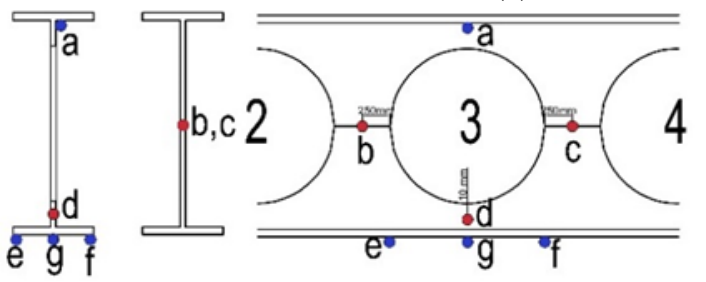

(c)

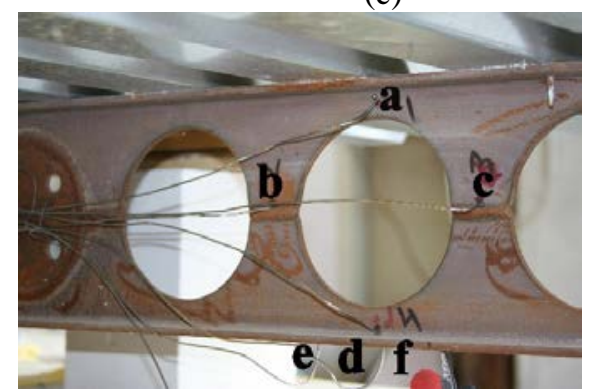

(e)

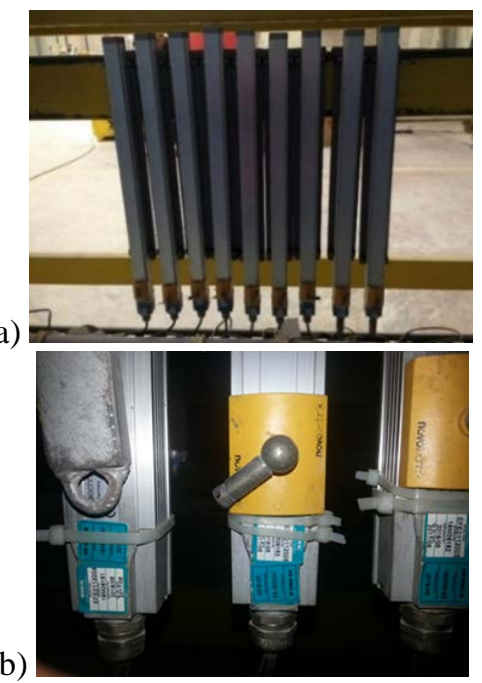

Şekil 8. Deneylerde kullanılan yerdeğiştirme ölçerler: (a) Yerdeğiştirme ölçerlerin görünümü, (b) Lineer cetvellerin magnetic okuyucu sensor bölümleri
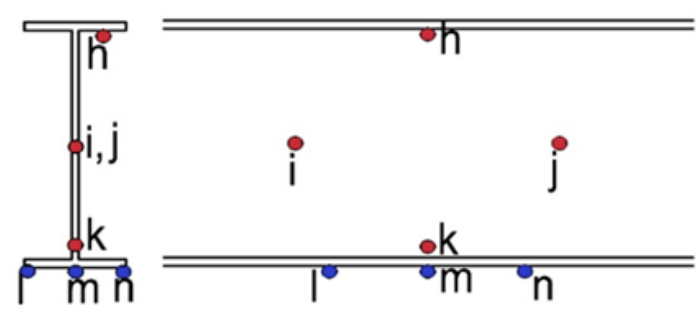

(b)
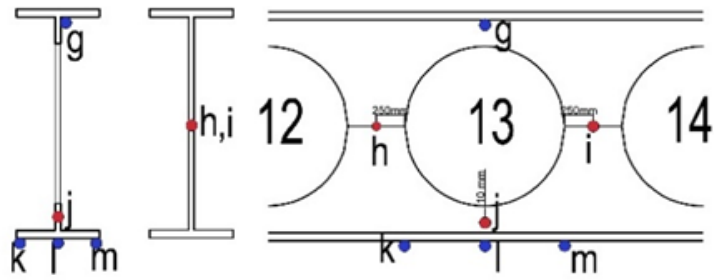

(d)

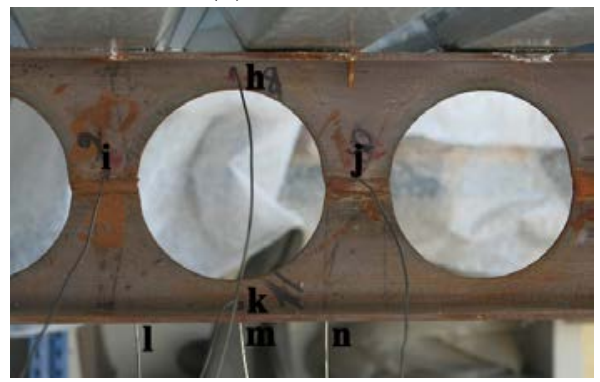

(f) 


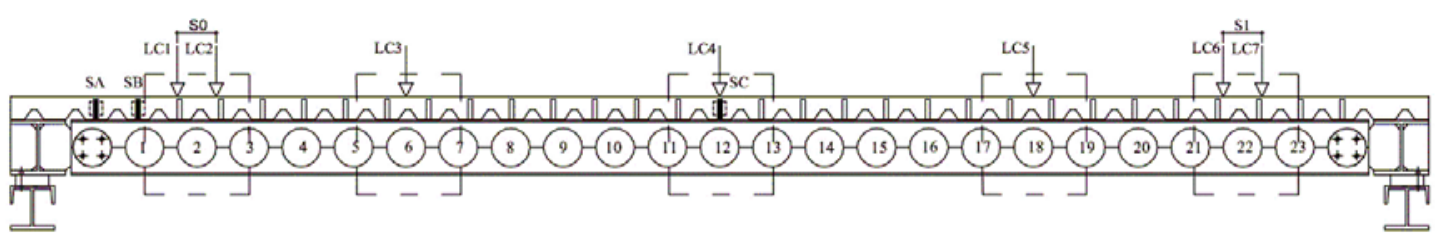

(g)

Şekil 9. Isılçiftlerin deney numuneleri üzerinde yerleşimi: (Şekil 9 a, b, c, d, e, f). (a) Dolu gövdeli kirişte mesnete yakın bölgedeki ısıl çiftlerin yerleşimi, (b) Dolu gövdeli kirişte kiriş orta noktasında isıl çiftlerin yerleşimi, (c) Gövdesi dairesel boşluklu kirişte mesnete yakın bölgedeki 1sıl çiftlerin yerleşimi, (d) Gövdesi dairesel boşluklu kiriş orta noktasında ısıl çiftlerin yerleşimi, (e) Gövdesi dairesel boşluklu kirişlerde mesnete yakın bölgeye yerleştirilen 1sıl çiftlerin görünümü, (f) Gövdesi dairesel boşluklu kirişlerde kiriş orta noktasına yerleştirilen ısıl çiftlerin görünümü, (g) Yerdeğiştirme ölçerlerin yerleşimi (ön görünüşs).

* Mavi renkli ısılçiftler üst ve alt başlığa yerleştirilen kırmızı renk ile gösterilenler ise gövdeye yerleştirilen 1 sıl çiftleri ifade etmektedir.

\section{DENEYSEL GÖZLEMLER VE DEĞERLENDİRMELER}

\subsection{Dolu Gövdeli (DK-R) ve Gövdesi Dairesel Boşluklu (GBK-YS) Numunelerinin Deney Sonuçları}

Deney sonrası numuneler incelendiğinde dolu gövdeli kompozit kirişin (DK-R), aşırı deformasyonlara ulaşılmasına karşın, iki profili birleştiren kaynak dikişi boyunca göçme, gövde burkulması ya da üst ve alt $\mathrm{T}$ elemanlarında yırtılmalar gözlenmemiştir. Kirişin, açıklığının orta noktasından (LC4 bölgesinden) düzlem dışına doğru burkularak, burulmalı bir deformasyonla göçtüğü tespit edilmiştir (Şekil 10,11). Bu göçme biçiminin, L/20'ye ulaşılması sonrasında sıcaklığın artışına bağlı olarak kirişin aşırı yerdeğiştirme sonrasında yükün ortaya yığılması sonucu kirişin yanal burulmalı burkulma yaparak mesnetlerinden ayrılması ile gerçekleştiği izlenmiştir.

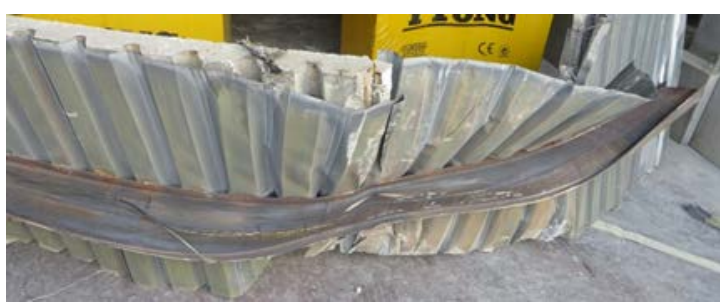

Şekil 10. Yanal burulmalı burkulma göçme modu
Kirişin mesnet noktalarında yer alan bulon deliklerinde ve bulonlarda herhangi bir sorun tespit edilmemiştir (Şekil 11). Kiriş ortasında LC4 ve ortaya yakın bölgelerde LC3, LC5'de döşeme içindeki bazı boyuna donatılarda kopmalar meydana gelmiştir. Kayma bağlantılarında herhangi bir ayrılma gözlenmemiştir. Betonarme döşeme ile trapez sac arasında tüm kiriş boyunca ve özellikle LC4 bölgesinde artan açılmalar izlenmiştir.

Çelik sacın kirişe mesnetlendiği noktalarda, özellikle mesnet bölgelerinde çukurlaşmalara rastlanması, bu bölgelerde mesnetlerin ezildiğini göstermektedir. Bu numunede gözlemlenen en önemli göçme modları olarak mesnet bölgelerinde betonarme döşeme ile trapez sac arasındaki ayrılmalar ve kirişte meydana gelen yanal burulmalı burkulma verilebilir (Şekil 10).

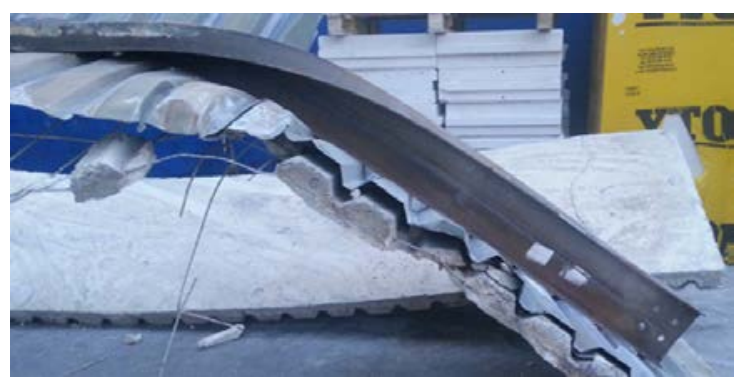

Şekil 11. Deney sonrası kirişin mesnet bölgesinin görünümü 
Deney sonrasında gövdesi dairesel boşluklu numune (GBK-YS) incelendiğinde (Şekil 12), çelik kirişin her iki mesnet noktasına yakın olan bölgelerdeki gövde boşluklarının arasında kalan bölümlerde yerel burkulmalar meydana geldiği görülmüştür; bu tür bir hasar durumu önceki çalışmalarda da benzer şekilde izlenmiştir [1-3].

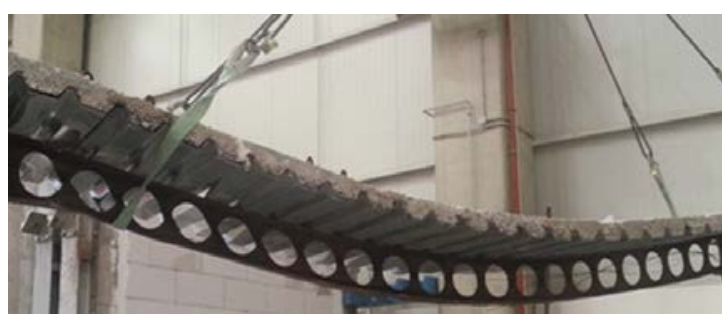

Şekil 12. Deney sonrası GBK-YS numunesinin genel görünümü

Kirişin mesnet noktalarından lineer cetvel 6 ve 7 (LC6 ve LC7) bölgesine denk gelen bölümde belirgin düzlem dışına doğru burkulmalar saptanmış olup aynı bölgede alt başlıkta da aşırı deformasyonlar olduğu belirlenmiştir (Şekil 13a).

LC6 ve LC7 bölgesinde trapez çelik levha ile beton arasında ayrılmalar olmadığı tespit edilmiştir. $\mathrm{Bu}$ da başlıklı saplamaların kompozit davranışı deneyin sonuna dek desteklediğini göstermektedir (Şekil 13a). Diğer mesnete yakın uçta LC1, LC2 ve LC3'ün konumlandı̆̆ 1 bölgede mesnetten itibaren gövde burkulmaları görülmüştür (Şekil 13b). Mesnete yakın iki uçta da dairesel boşluklarda Vierendeel göçme mekanizmasına bağlı olarak daireden elipse doğru şekil değişikliği saptanmıştır. Daire boşluklarında deformasyona bağlı olarak en belirgin çap değişikliği LC6- LC7 bölgesinde gelişmiş olup kısa ve uzun çaplar sırasıyla $D_{1}=11 \mathrm{~cm}$ ve $D_{2}=17$ cm olarak ölçülmüştür (Şekil 13a).

Kiriş açıklığının orta bölgesi LC4'de deplasman değeri yüksek ve kalıcı olmasına karşın, mesnet noktalarındaki gözlenen belirgin gövde burkulmaları, alt başlıklarda deformasyon ve daire boşluklarında Vierendeel etkisine bağlı şekil değişikliği beklendiği üzere kesme kuvvetlerinin görece daha düşük olması nedeniyle bu bölgede gözlenmemiştir.

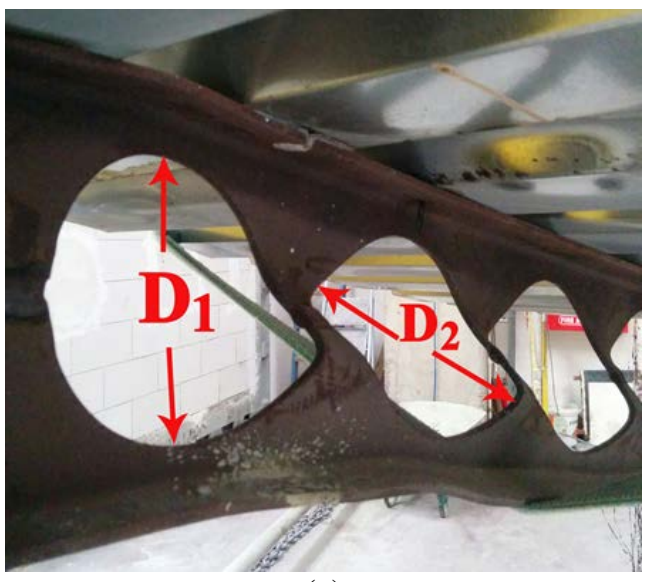

(a)

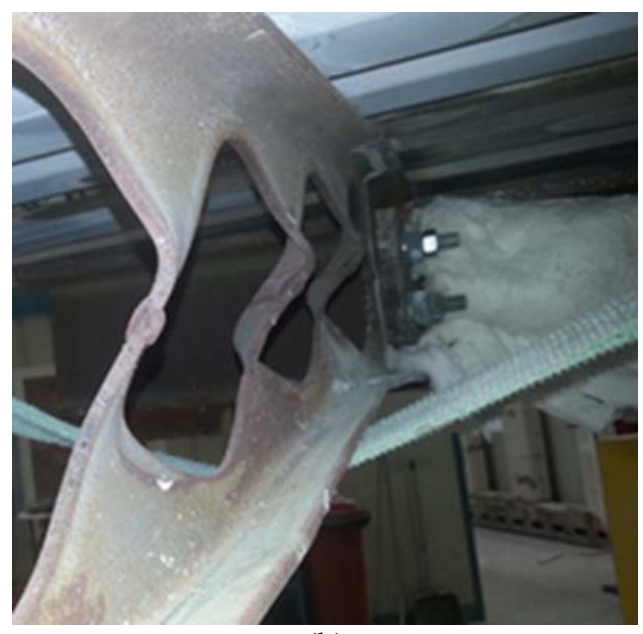

(b)

Şekil 13. GBK-YS numunesi deney sonuçları: (a) LC6 ve 7'de meydana gelen gövde burkulması ve Vierendeel göçme, (b) LC1 ve LC2 bölgelerinin görünümü

DK-R numunesinde yerdeğiştirmeler kiriş açıklığının L/20'sine ulaştığı değerde $\mathrm{t}=40$ dakika olarak kaydedilmiştir. Sıcaklık değerleri incelendiğinde en düşük sicaklıklara mesnete yakın bölgede, gövde yüksekliğinin orta noktası olan c $\left(798,4{ }^{\circ} \mathrm{C}\right)$ ve kiriş açıklığının orta bölgesinde üst başlığa yakın olan $\mathrm{h}\left(821,5{ }^{\circ} \mathrm{C}\right)$ noktalarında ulaşılmıştır.

Mesnete yakın olan bölgede yer alan e $\left(874,3^{\circ} \mathrm{C}\right)$ ve yine aynı bölgede alt başlığa yakın olan $\mathrm{d}$ 
$\left(858,3^{\circ} \mathrm{C}\right)$ noktalarında en yüksek sıcaklık eğrileri elde edilmiştir (Şekil 14).

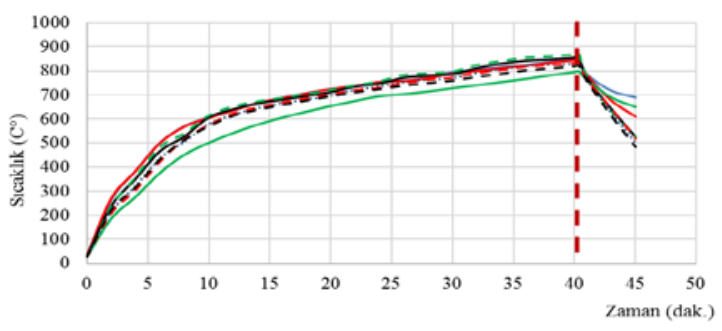

Şekil 14. DK-R numunesinin sıcaklık-zaman eğrisi

Lineer cetvellerden elde edilen yerdeğiştirmeler, sıcaklığa ve zamana bağlı olarak Şekil 15 ve Şekil 16'da verilmektedir. Deney sirasinda numune mesnetlerinden kurtulup kontrol dişı firının içine düştüğü için deney sonrasında deformasyon ölçümü alınamamıştır. En yüksek yerdeğiştirme kiriş açıklığının dörtte birine yerleştirilmiş olan LC5'de ölçülmüş̧tür. $\mathrm{Bu}$ noktada göçme değerine (L/20) karşı gelen $890,4{ }^{\circ} \mathrm{C}$ 'de ve 40 . dakikada $\delta_{\text {göçme }}=237,7 \mathrm{~mm}$ 'dir (Şekil 17). Deney, $892,4{ }^{\circ} \mathrm{C}$ ve 40,3 dakikada sonlandırıldığında en büyük yerdeğiştirme verisi LC5 bölgesinde $\delta_{\text {maks }}=291,5 \mathrm{~mm}$ olarak kaydedilmiştir.

Yerdeğiştirme verileri incelendiğinde en yüksek değerin kiriş açıklığının orta noktasından mesnet noktasına doğru kaydığı ve yerdeğiştirmelerdeki artışların simetrik olarak yerleştirilen lineer cetvellerde düzensizlik gösterdiği görülmektedir (Şekil 15, Şekil 16).

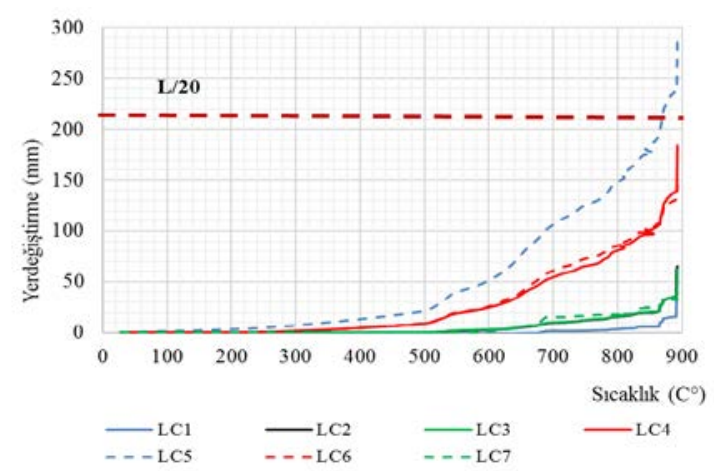

Şekil 15. DK-R numunesi yerdeğiştirme-sıcaklık eğrisi
Kirişin göçme noktasına ulaştıktan sonra sıcaklığın artışına bağlı olarak yüklerin mesnet noktasına doğru yığılmasının neden olduğu tespit edilmiştir.

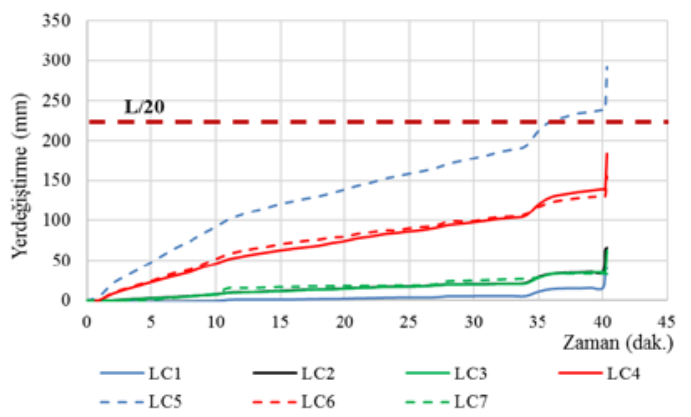

Şekil 16. DK-R numunesi yerdeğiştirme-zaman eğrisi

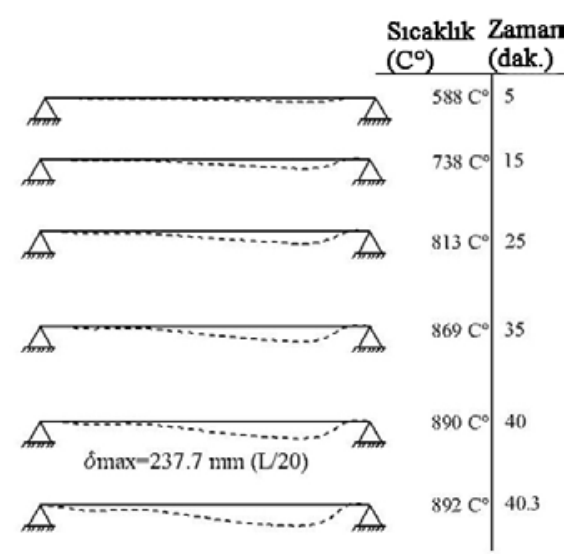

Şekil 17. DK-R numunesinin belirli zaman ve sıcaklık aralıklarındaki yerdeğiştirme verileri

GBK-YS numunesinde göçme, $t=24,5$ dakika'da maksimum düşey yerdeğiştirmenin standartlar tarafından belirtilmiş olan kiriş açıklığının L/20'sine ulaştığı değerde gerçekleşmiştir. L/20 değeri, TS EN $1365-3$ ve EN 1363-3 standartlarında belirtildiği gibi kirişte meydana gelebilecek maksimum yerdeğiştirmeyi ifade etmektedir.

GBK-YS numunesinin sicaklık değerleri incelendiğinde, en düşük sıcaklıklara LC1-LC2 ve LC6-LC7 bölgesinde üst başlığa yakın bölge a $\left(635,9^{\circ} \mathrm{C}\right) \mathrm{h}\left(717,4^{\circ} \mathrm{C}\right)$ ile LC1-2 bölgesi gövde ortasında b $\left(723,4{ }^{\circ} \mathrm{C}\right)$ noktasında, en yüksek sıcaklığa kiriş açıklığının ortasında alt başlığa 
yerleștirilmiş olan $\mathrm{m}\left(808,1^{\circ} \mathrm{C}\right), 1\left(811,1^{\circ} \mathrm{C}\right)$ ve $\mathrm{n}$ $\left(811,2^{\circ} \mathrm{C}\right)$ noktalarında ulaşıldığ

Betonarme döşemenin varlığı beklendiği üzere, üst başlıkta elde edilen sicaklık verilerinin alt başlığa göre daha düşük düzeylerde kalmasına neden olmuştur (Şekil 18).

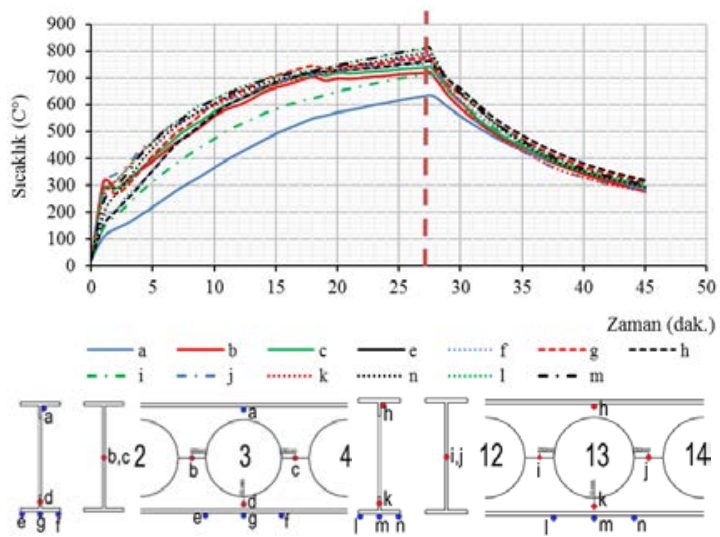

Şekil 18. GBK-YS numunesinin sıcaklık-zaman eğrisi

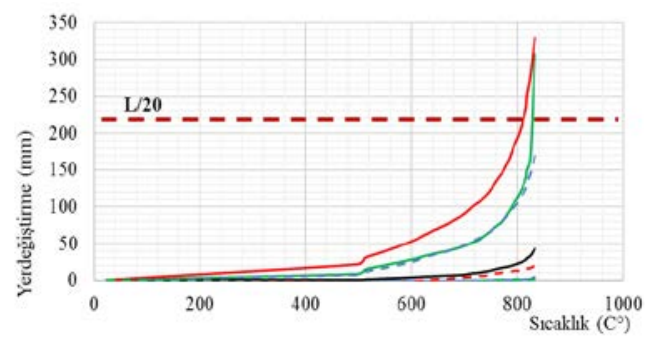

a)
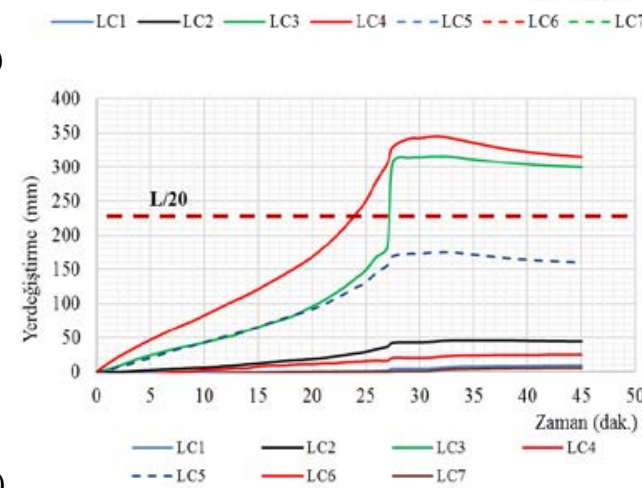

Şekil 19. GBK-YS numunesinin yerdeğiştirme grafikleri (a) GBK-YS numunesi yerdeğiştirme-sıcaklık eğrisi, (b) GBKYS numunesi yerdeğiştirme-zaman eğrisi
GBK-YS numunesinde lineer cetvellerden elde edilen yerdeğiştirmeler, sıcaklığa ve zamana bağlı olarak Şekil 19a ve Şekil 19b’de verilmiștir. $500{ }^{\circ} \mathrm{C}$ sicaklığa ulaşıldığında yerdeğiştirmelerde belirgin bir artış görülmektedir. En yüksek yerdeğiştirme kiriş açıklığının orta noktasında LC4'de ölçülmüştür. Bu noktada göçme değerine (L/20) karşı gelen sıcaklık $816{ }^{\circ} \mathrm{C} 24,5$. dakika'da gerçekleşmiş ve göçme 239.2 mm'de oluşmuştur (Şekil 20). Deney, $832{ }^{\circ} \mathrm{C}$ ve 27,5. dakika'da sonlandırıldığında en büyük yerdeğiştirme verisi LC4 bölgesinde 329,3 mm olarak kaydedilmiştir.

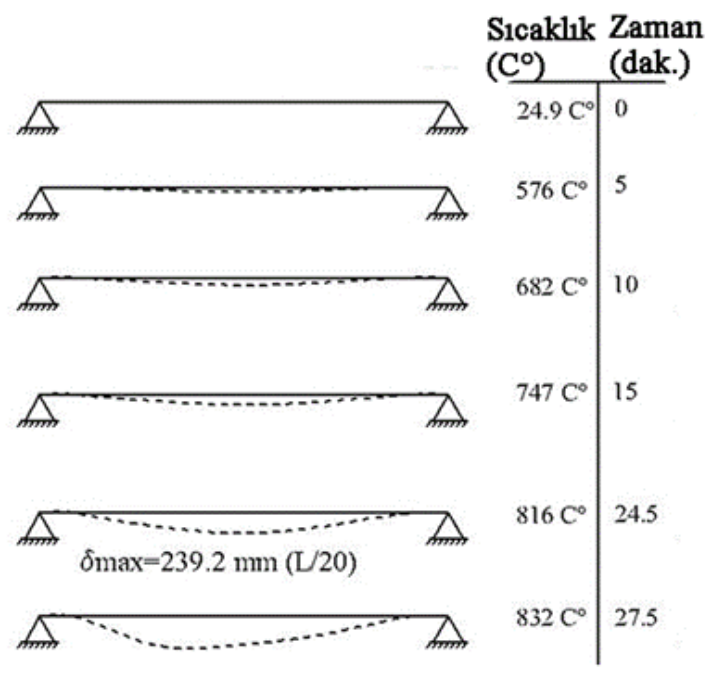

Şekil 20. GBK-YS numunesinin belirli zaman ve sıcaklık aralıklarındaki yerdeğiştirme verileri

Kiriş açıklığında, dörtte birinde simetrik olarak yerleştirilen LC 3 ve LC5'de ölçülen yerdeğiştirmeler sırasıyla $307,1 \mathrm{~mm}$ ve $169 \mathrm{~mm}$ olarak LC4'den sonra en yüksek değerlerdir. LC2 ve LC6'da okunan değerler ise sirasıyla 42,3 mm ve 19,9 mm'dir. Mesnet noktalarına en yakın ve birbirlerine simetrik olarak konumlandırılan LC1 ve LC7'de deney sonunda en düşük değerler olan 4,57 mm ve 0,7 mm'ye ulaşılmıştır. Yerdeğiştirme verileri incelendiğinde, kiriş açıklığının orta noktasından mesnet noktalarına doğru gidildikçe yerdeğiştirme değerlerinde azalma olduğu görülmektedir. 
Gövdesi Dolu ve Dairesel Boşluklu Yalıtımsız Kompozit Döşeme Kirişlerinin Yangın Davranışının Deneysel Incelenmesi

\subsection{Kompozit Döşeme Davranışı}

Dolu ve gövdesi boşluklu numunelerin yangın deneyleri sonrası kompozit betonarme döşemede meydana gelen hasarlar incelendiğinde iki türden (boyuna ve enine) çatlak belirlenmiştir. Bu çatlaklar; kirişin üzerinde açıklık boyunca (kiriş ekseni üzerindeki başlıklı saplamaları izleyen), ikincisi kiriş eksenine dik olarak devam etmekte olan çatlaklardır (Şekil 21a, b). Kiriș eksenine dik çatlakların mesnete yakın bölgelerde kesme kuvvetinin yüksek olmasina bağlı olarak Vierendeel etkisi ile birlikte gövdede yerel burkulmaların artmasına bağlı olarak üstkatmandaki betonu çatlatarak enine çatlakların oluşmasına yol açtığı tespit edilmiştir. Kiriş ekseni boyunca ilerleyen başlıklı saplamaları izleyerek devam eden çatlakların yanısıra DK-R numunesinin betonunda kesme kuvvetine bağl1 beton kalınlığı boyunca ilerleyen eğik çatlaklar da gözlemlenmiştir.

Deney sonuçlarında her iki numunede de bazı noktalarda (özellikle iki yan yüzeyde) çelik sac ile döşeme arasında ayrılmalar görülmüsstür. $\mathrm{Bu}$ ayrılmalar aderans kaybını göstermektedir. Beton ve çelik arasındaki ayrılmalar çeliğin pürüzsüz olmasından kaynaklanmaktadır. Ayrılmaların mesnet bölgelerinde daha fazla olduğu, kiriş açıklığının ortasına doğru gidildikçe azaldı ̆̆ı görülmektedir.

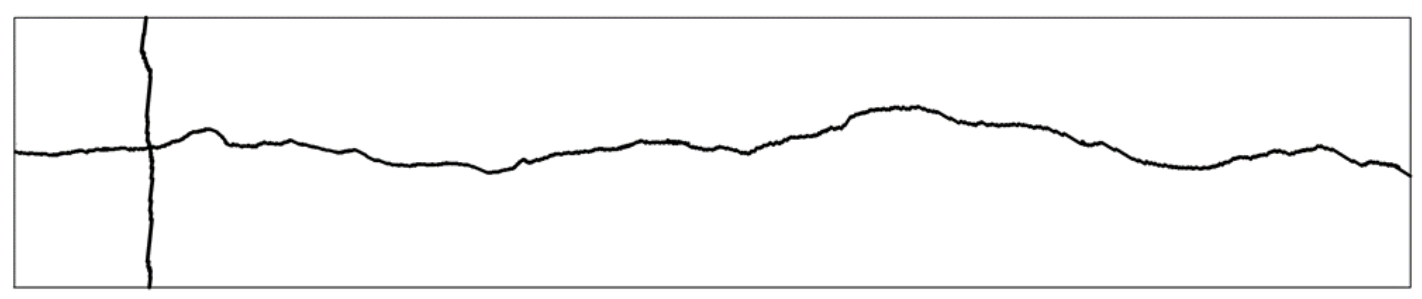

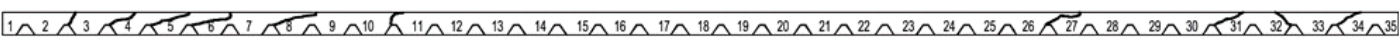

(a)

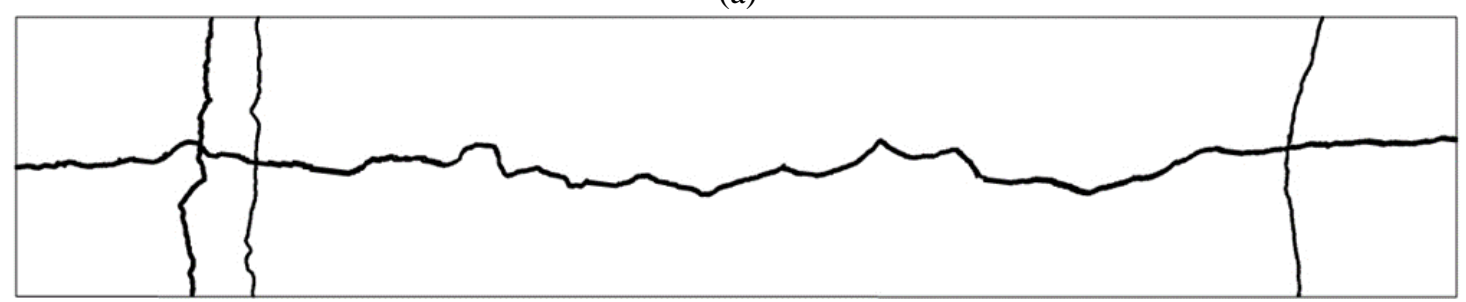

(b)

Şekil 21. Numunelerin deney sonrası beton çatlak haritaları (üstten görünüş): (a) DK-R numunesinin deney sonrası betonarme döşemesi, (b) GBK-YS numunesinin deney sonrası betonarme döşemesi

\section{GENEL DEĞERLENDİRME VE KARŞILAŞTIRMA}

GBK-YS ve DK-R numunelerinin genel sicaklıkzaman grafiği incelendiğinde GBK-YS numunesinin göçme anına kadar sıcaklık değerlerinde az bir fark gözlenmiştir. GBK-YS göçmeye 24,5 dakika'da $743,9{ }^{\circ} \mathrm{C}$ ile, DK-R numunesi ise 40 dakika'da 836,7 $\mathrm{C}^{\circ}$ ile ulaşmıștır (Şekil 22 a).

Gövde boşluklu GBK-YS ve dolu DK-R numunelerinden elde edilen sicaklıklar karşılaştırıldığında, mesnet bölgesinde üst başlıkta göçme anında en yüksek sıcaklık dolu gövdeli DK-R numunesinde $847,6{ }^{\circ} \mathrm{C}$ olurken, gövde boşluklu numunede $611,6 \quad{ }^{\circ} \mathrm{C}$ 'dir. Gövde 
S1caklıkları ise DK-R numunesinde $820,2{ }^{\circ} \mathrm{C}$, GBK-YS numunesinde $721,3^{\circ} \mathrm{C}$ 'dir.

Aynı bölgede alt başlık sıcaklıkları dolu gövdeli numunede $846,7^{\circ} \mathrm{C}$ ve boşluklu gövdeli numunede ise $750,7^{\circ} \mathrm{C}$ 'dir (Şekil $22 \mathrm{~b}$ ).

Kiriş açıklığının orta bölgesinde üst başlık sicaklıkları DK-R numunesinde $728,8{ }^{\circ} \mathrm{C}$, GBK-YS numunesinde 695,9 ${ }^{\circ} \mathrm{C}$ olarak ölçülmüştür. $\mathrm{Bu}$ bölgede GBK-YS numunesinde gövde sıcaklığı 765,9 C C $^{\circ}$ olarak kaydedilmiştir (Şekil 22c).

Dolu gövdeli yalıtımsız DK-R numunesi, gövde boşluklu ve yalıtımsız GBK-YS numunesine göre daha uzun süre yangına dayanım (40 dk)

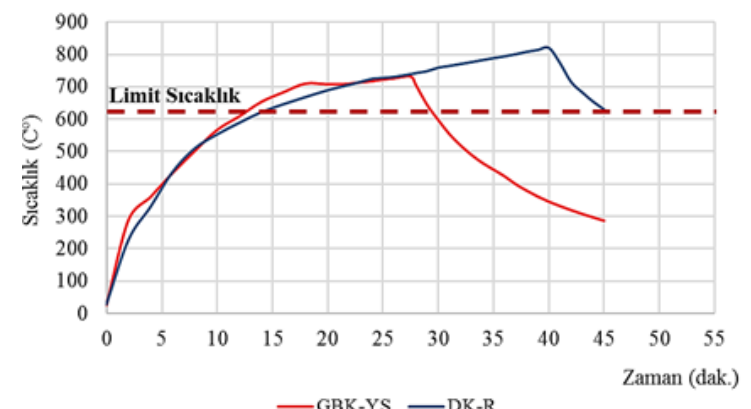

(a)

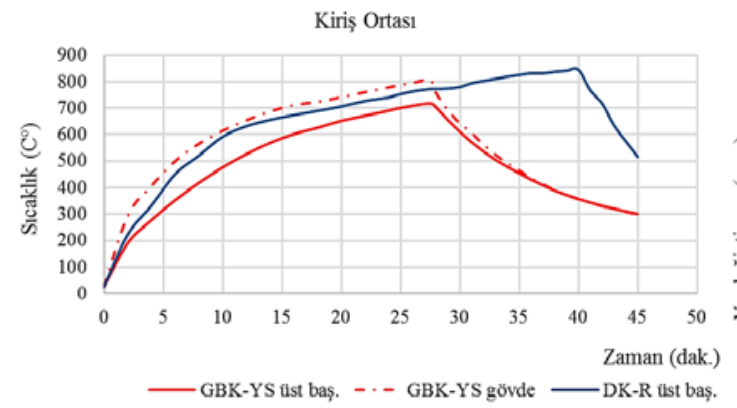

(c) göstermiștir. Numuneler karşılaştırıldığında en hızlı sıcaklık artışının yaşandığı numune gövde boşluklarına sahip olması nedeniyle GBK-YS'dir. GBK-YS numunesi kesit özellikleri nedeniyle 24,5 dakika'da göçme sınırına ulaşmıştır. Gövde boşluklu ve boşluksuz yalıtımsız numunelerde göçme sırasında meydana gelen yerdeğiştirmeler incelendiğinde ise en büyük yerdeğiştirme beklendiği üzere gövdesi boşluklu GBK-YS numunesinde $239,25 \mathrm{~mm}$ olarak elde edilmiştir. Dolu gövdeli DK-R numunesinde ölçülen yerdeğiştirme de 237,73 mm'dir (Şekil 22 d).

En hızlı ve en yüksek yerdeğiștirme sınırına varan dolayısıyla yangın dayanımı en düşük GBK-YS numunesi olmuştur.

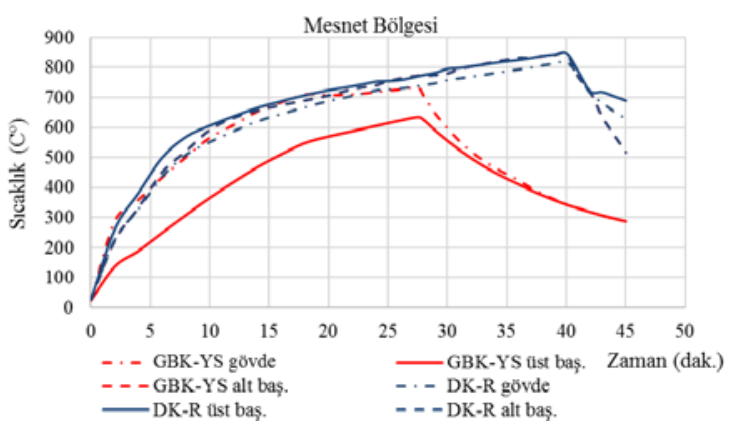

(b)

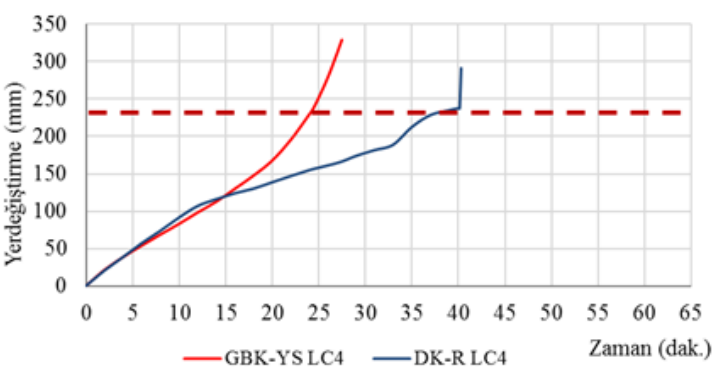

(d)

Şekil 22. Yalıtımsız numunelerin deney sonuçlarının karşılaştııılması: (a) DK-R ve GBK-YS numunelerinin genel sicaklık-zaman grafiği (b) Mesnet bölgesi DK-R ve GBK-YS numunelerinin gövde, alt ve üst başlık sicaklık-zaman eğrisi, (c) DK-R ve GBK-YS numunelerinin kiriş ortası bölgesine ait gövde, alt ve üst başlık sıcaklık-zaman eğrisi, (d) Kiriş açıklığının ortasında (LC4) DK-R ve GBK-YS numunelerinin yerdeğiştirme-zaman eğrileri

Yangın deneyleri sonrasında yüksek sicaklıklara maruz kalan numunelerin deney sonrası mekanik özelliklerinde meydana gelen olası değişimleri belirleyebilmek amaciyla her iki numunenin çelik 
Gövdesi Dolu ve Dairesel Boşluklu Yalıtımsız Kompozit Döşeme Kirişlerinin Yangın Davranışının Deneysel Incelenmesi

profillerden alınan kupon numunelere çekme deneyi yapılmıştır. Çekme deneyi için profillerden oksijenli kesim yapılarak GBK-YS numunesinden 1, DK-R numunesinden 1, toplam 2 parça alınmıştır (Şekil 23a). Bu parçalar özellikle deformasyonun az olduğu bölgelerden alınarak çelik kirişler için TS EN ISO 6892-1 (Metalik Malzemeler-Çekme Deneyi-Bölüm 1: Ortam Sıcaklığında Deney Metodu) standardına göre çekme numunesi boyutları belirlenerek, üretimleri yapılmıştır (Şekil 23b).

Deney sonrası kupon numune sonuçlarına bağlı olarak Çizelge 1 hazırlanmıştır.

Çizelge 1. Deney sonrası numunelerin mekanik özellikleri

\begin{tabular}{|l|c|c|c|}
\hline & $\begin{array}{c}\text { Akma } \\
\text { Gerilmesi } \\
(\mathrm{MPa})\end{array}$ & $\begin{array}{c}\text { Çekme } \\
\text { Dayanımı } \\
(\mathrm{MPa})\end{array}$ & $\begin{array}{c}\text { Kopma } \\
\text { Uzaması } \\
(\%)\end{array}$ \\
\hline DK-R & 332 & 479 & 28,1 \\
\hline GBKYS & 307 & 416 & 11,4 \\
\hline
\end{tabular}

Buna göre, GBK-YS numunesinde, deney sonrası öncesine göre, akma gerilmesinde en fazla \%2 ve en az 0,8'lik bir azalma olduğu, çekme dayanımında ise \%5 ile \%7,5 arasında azalma ve kopma uzamasının da \%65 azaldığı görülmektedir. DK-R numunesinin, deney öncesi ve sonrası verileri incelendiğinde, akma gerilmesinde en fazla $\% 7$ ile en az \%5'lik bir artıs olduğu, çekme dayanımında $\% 6$ ile $\% 8$ arasında artı̧ ve kopma uzamasında ise \%9,6'lı bir azalma olduğu kaydedilmiştir.

Kupon numunelerinin deney öncesi ve sonrası mekanik özellikleri incelendiğinde yangına maruz kalan korumasız GBK-YS numunesinin akma gerilmelerinde ve çekme dayanımlarında az da olsa bir azalma gözlenmiştir. DK-R numunesinin akma gerilmesinde ve çekme dayanımında önemsiz denebilecek artı̧lar kaydedilmiştir. Kopma uzamasındaki en büyük azalma $\% 65$ 'lik bir azalma ile GBK-YS numunesinde elde edilmiştir. Bu sınırlı deneysel çalıșmada, yangın sonrasında çeliğin akma ve çekme dayanımında çok büyük değişikliğe neden olmadığı, buna karşın özellikle kopma uzamasında önemli azalmalara neden olabileceği sonucu çıkmaktadır. a)

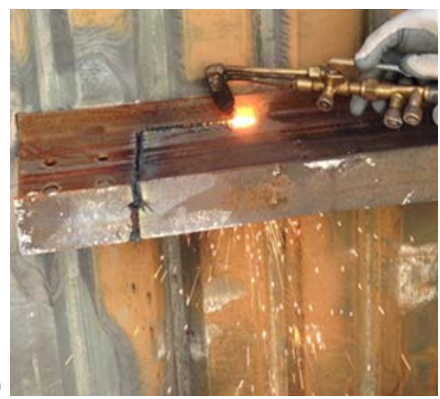

b)

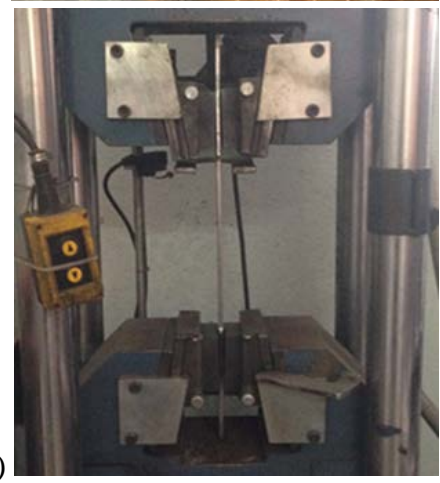

Şekil 23. Yangın deneyleri sonrası çekme deneyleri: (a) DK-R numunesinden kupon numune alımı, (b) Çekme presi

\section{SONUÇLAR}

Gövdesi dolu ve dairesel boşluklu numunelerin sınırlı sayıdaki ve özelliklerdeki yangın deneylerinden elde edilen sonuçlar aşağıda özetlenmiştir:

- Gövdesi boşluklu GBK-YS ve iki profilin kaynaklanması ile oluşturulan dolu gövdeli DK-R numunesinde deney sonras1 yapilan kapsaml1 incelemelerde kaynak bölgelerinde herhangi bir sorun meydana gelmediği tespit edilmiştir.

- Sıcaklık verileri karşılaştırıldığında, göçme (L/20'de) sıcaklığına en hızlı $(24,5 \mathrm{dk})$ ulaşan numunenin gövde boşluklu yalıtımsız GBK-YS numunesi olduğu görülmüştür.

- Yalıtımsiz ve dolu gövdeli DK-R numunesi (41 $\mathrm{dk}$ ) beklenildiği üzere yalıtımsız gövde boşluklu GBK-YS (24,5 $\mathrm{dk}$ ) numunesine göre daha uzun süreli bir yangın dayanımı sağlamıştır. Böylece, gövde boşluklarının yangın dayanımı 
önemli düzeyde azalttığı anlaşılmaktadır. Başka bir deyişle, bu tür kirişlerin koruma olmaksızın kullanımlarının mümkün olamayacağı ve yönetmeliklerde öngörülen dayanım değerlerine/sürelerine ulaşamayacağı anlaşılmaktadır.

- Numunelerin yerdeğiştirme oranları karşılaştırıldığında, göçme anında en büyük yerdeğiştirme, yüklerin sıcaklığa bağlı olarak kirişin orta bölgesine yığılması sonucu DK-R numunesinde 291,5 mm ile gerçekleşmiştir.

- DK-R numunesinde ana göçme modu yanal burulmalı burkulma iken GBK-YS numunesinde Vierendeel etkisiyle birlikte mesnet bölgesi civarında gövde burkulmaları öne çıkmaktadır.

- Çelik kompozit kiriş numunelerinin yangın deneyi öncesi ve sonrası mekanik özellikleri incelendiğinde en fazla değişimin (azalmanın) kopma uzamasında $\% 20$ ile yalıtımsız gövde boşluklu GBK-YS numunesinde olduğu tespit edilmiştir. Akma ve çekme dayanımlarındaki değişim ihmal edilecek kadar azdır.

- Numunelerin hiçbirinde bulon deliklerinde, bulonlarda ve üst başlık kayma bağlantı elemanlarında (studlarda) göçme gözlenmemiştir.

\section{TEŞEKKÜR}

$\mathrm{Bu}$ çalışma, 315M285 numaralı proje kapsamında TÜBITAK-1002- Hizlı Destek Programı ve ITTÜ-BAP 3802 no'lu proje kapsamında İTÜ tarafından desteklenmiştir. Deney numunelerinin üretimi GALPAN tarafından gerçekleştirilmiştir.

\section{KAYNAKLAR}

1. Najdai, A., Vassart, O., Ali, F., Talamona, D., Allam, A., Hames, M., 2007. Performance of Cellular Composite Floor Beams at Elevated Temperatures, Fire Safety Journal, 42, 489- 497.

2. Najdai, A., Petrou, K., Han, S., Ali, F., 2016. Performance of Unprotected and Protected
Cellular Beams in Fire, Journal of Construction and Building Materials, 105, 579-588.

3. Bailey, C.G., 2004. Indicative Fire Tests to Investigate the Behaviour of Cellular Beams Protected with Intumescent Coatings, Fire Safety Journal, 39, 689-709.

4. Bihina, G., Zhao, B., Bouchair, A., 2012. Experimental and Numerical Investigation on the Behaviour of a Composite Floor Made of Cellular Beams in a Fire Situation, $7^{\text {th }}$ International Conference on Structures in Fire, (295-304). Zurich Switzerland: ETH Zurich, June 6-8.

5. Bihina G., Zhao, B., Bouchair, A., 2013. Behaviour of Composite Steel-Concrete Cellular Beams in Fire, Journal of Engineering Structures, 56, 2217-2228.

6. Selamet, S., Yolaçan, T.F., 2017. ÇelikBetonarme Kompozit Kat Döşemesi Yangın Dayanım Deneyi, İMO Teknik Dergi, Temmuz, 8007-8022.

7. Nyugen, T.T., Tan, K.H., 2012. Testing of Composite Slab-Beam Systems at Elevated Temperatures, Proceedings on the $7^{\text {th }}$ International Conference on Structures in Fire, Zurich, Switzerland, 6-8 June, 247- 256.

8. Vassart, O., Bailey, C.G., Bihina, G., Hawes, M., Nadjai, A., Peigneux, C., Simms, W.I., Franssen, J.M., 2010. Parametrical Study on The Behaviour of Steel and Composite Cellular Beams Under Fire Conditions. Proceedings of the $6^{\text {th }}$ International Conference on Structures in Fire (SIF'10), USA: Michigan State University.

9. TS EN 1363-1. 2013. Yangına Dayanıklılık Deneyleri- Bölüm 1- Genel Kurallar, Türk Standardları Enstitüsü, Ankara.

10.TS EN ISO 6892-1. 2011. Metalik Malzemeler- Çekme Deneyi- Bölüm 1: Oda Sicaklığında Deney Metodu, Türk Standartları Enstitüsü, Ankara.

11. EN 1363-1. 2012. Fire Resistance Tests-Part 1: General Requirements. CEN.

12. Li, Q.G., Guo, S.X., 2008. Experiment on Restrained Steel Beams Subjected to Heating and Cooling, Journal of Constructional Steel Research, 64, 268-274. 
Gövdesi Dolu ve Dairesel Boşluklu Yalıtımsız Kompozit Döşeme Kirişlerinin Yangın Davranışının Deneysel Incelenmesi

13. Kallerova, P., Wald, F., 2009. Fire Test on Experimental Building in Mokrsko, CTU in Prague.

14. Lawson, R.M., Hicks, S.J., 2011. Design of Composite Beams with Large Web Openings: In Accordance with Eurocodes and the U.K. National Annexes Technical Report (SCI P3559), Steel Construction Institute.

15. Sanghoon, H., Petrou, K., Naili, E.L., Nadjai, A., Ali, F., 2012. Behaviour of Protected Cellular Beams Having Different Opening Shapes in Fire Conditions, In M. Fontana, A. Frangi and M. Knobloch (Ed.), $7^{\text {th }}$ International Conference on Structures in Fire, (75-83) Switzerland: ETH Zurich, June 6-8.

16. Wang, Y., Jia, L., Li, X., 2018. Investigation on Behavior of Castellated Composite Beams Under Fire, International Forum on Construction, Aviation and Environmental Engineering-Internet of Things, Guangzhou, China.

17. ISO 834-1. 2009. Fire-resistance TestsElements of Building Construction Part 1: General Requirements, International Organization for Standardization. Retrieved from https://www.sis.se/api/document/preview /615580/

18. TS 498. 1997. Yap1 Elemanlarının Boyutlandırılmasında Alınacak Yüklerin Hesap Değerleri, Türk Standartları Enstitüsü, Ankara.

19. TS EN 1365-3. 2003.Yangına Dayanıklılık Deneyleri-Yük Taşıyıcı Elemanlar-Bölüm 3: Kirişler, Türk Standartları Enstitüsü, Ankara.

20. EN 1365-3. 1999. Fire Resistance Tests for Loadbearing Elements-Part 3: Beams, CEN. 